\title{
A Convenient Catalyst for Aqueous and Protein Suzuki-Miyaura Cross-Coupling
}

\author{
Justin M. Chalker, Charlotte S. C. Wood, and Benjamin G. Davis* \\ Chemistry Research Laboratory, Department of Chemistry, University of Oxford, 12 Mansfield Road, \\ Oxford OX1 3TA, U.K.
}

Received August 24, 2009; E-mail: ben.davis@chem.ox.ac.uk

The utility of palladium-catalyzed cross-coupling in organic synthesis is indisputable. ${ }^{1}$ With broad functional group tolerance and the advent of aqueous cross-coupling, ${ }^{2}$ it is not surprising these reactions have been explored in bioconjugation. In particular, crosscoupling on peptides ${ }^{3}$ and proteins ${ }^{4}$ has received much attention because of the prospect of selective formation of a nonlabile linkage at a residue functionally orthogonal to natural amino acids. ${ }^{5}$ Such modified proteins may then find use in a variety of biochemical and therapeutic contexts. ${ }^{6}$ Cross-coupling as a method for protein modification is particularly attractive since a variety of non-natural amino acid coupling partners can be genetically incorporated into peptides and proteins. ${ }^{4,7}$ Nonetheless, efficient cross-coupling on proteins remains an outstanding problem and efforts to date have suffered from low conversion ${ }^{4 \mathrm{c}}$ or required denaturing conditions. ${ }^{4 \mathrm{~d}}$ These reports prompt the need for readily available, active catalysts that mediate cross-coupling under benign conditions suitable for proteins: buffered aqueous media at ambient temperature.

As part of our continued interest in adapting the tools of organic chemistry to synthetic biology, ${ }^{8}$ we considered worthwhile an exploration of Suzuki-Miyaura cross-coupling ${ }^{9}$ on peptides and proteins. We restricted ourselves to phosphine-free catalysts that are commercially available. Phosphines are susceptible to oxidation, ${ }^{10}$ and it is convenient to have a system that does not require an inert atmosphere or degassed solvents. Moreover, phosphine ligands are often expensive and their price can exceed that of the palladium salt.

Exploratory work $^{11}$ on model systems led us to 2-amino-4,6dihydroxypyrimidine, a ligand used in Sonogashira cross-couplings in organic solvents. ${ }^{12} \mathrm{We}$ found that the sodium salt of this ligand forms a complex with $\mathrm{Pd}(\mathrm{OAc})_{2}$ that is freely soluble in water (Table 1). We were pleased to find that this system catalyzed Suzuki-Miyaura cross-couplings in good yields on amino acid and peptide models (Table 1). The couplings were run at $37{ }^{\circ} \mathrm{C}$ in buffered water. No organic solvent was used and no effort was made to exclude oxygen. ${ }^{13}$ The amino acid substrates in Table 1 were selected because they can be incorporated into proteins genetically (entries $1-4$ ) or chemically (entries $5-7))^{4,7}$ No reaction was observed under these conditions with 4-chlorophenylalanine (entry 3 ). Entry 6 indicates that $C$-terminal cysteine derivatives may inhibit this catalytic system, but internal alkyl-cysteines are tolerated and high yields were observed with the peptide in entry 7 containing the amino acid $p$-iodobenzyl cysteine (Pic). Free cysteine, however, is detrimental, and no cross-coupling was observed in interference experiments where reduced glutathione was added at the same loading as palladium. ${ }^{11}$

These promising results prompted validation of this catalytic system on a protein substrate. A model protein (1, Table 2) was obtained by chemically installing Pic at the single cysteine of subtilisin Bacillus lentus (SBL) mutant S156C. ${ }^{11} \mathrm{SBL}$ is a serine protease, and boronic acids are inhibitors of this protein, forming
Table 1. Model Cross-Couplings with Pd-pyrimidine Catalyst ${ }^{a}$

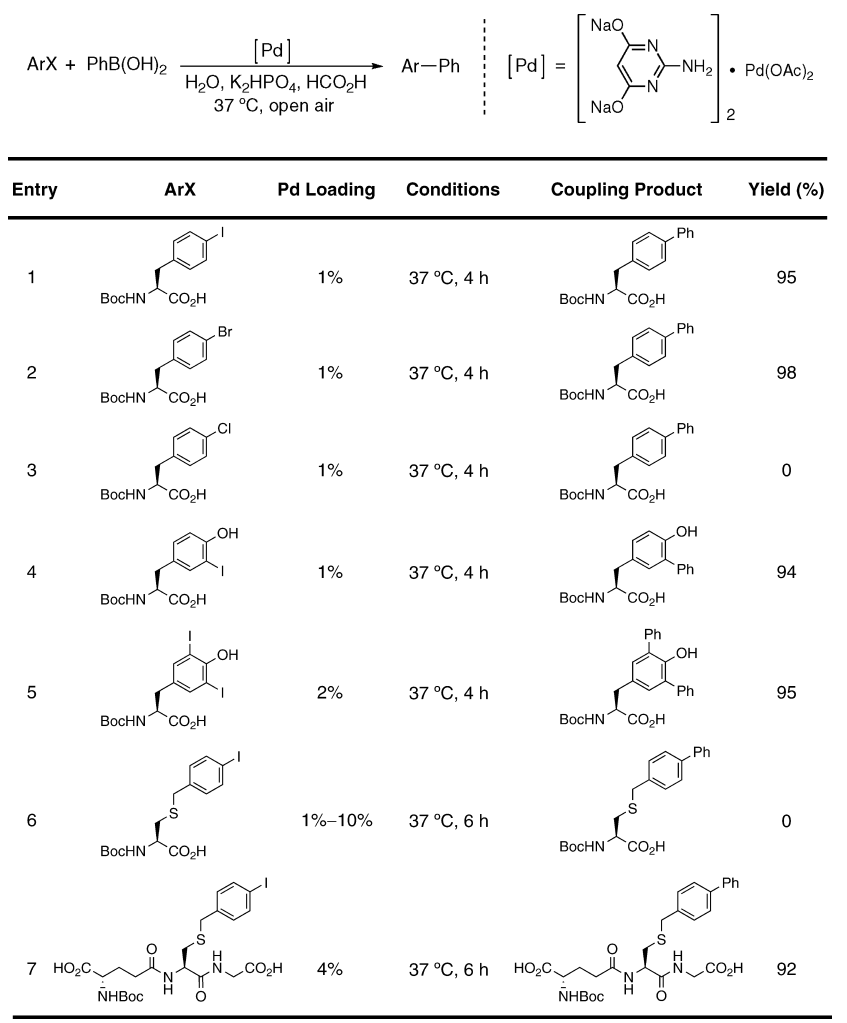

${ }^{a}$ For preliminary models and catalysts, see Supporting Information.

borates at the serine of the active site. ${ }^{14}$ The protein was therefore irreversibly inhibited by sulfonylation at S221 with phenylmethylsulfonylfluoride (PMSF) to avoid complications during the crosscoupling.

As a first attempt, phenylboronic acid was used as the crosscoupling partner (Table 2, entry 1). Gratifyingly, the coupling was complete within $30 \mathrm{~min}$ at $37^{\circ} \mathrm{C}$, as monitored by LC-MS. While an excess of palladium (50 equiv) and boronic acid (500 equiv) was used to ensure rapid coupling, these reagent loadings are still lower than the thousands of equivalents often employed in protein modification. ${ }^{15}$ In control experiments, only unreacted starting material was observed when $\mathbf{1}$ was treated with palladium or phenylboronic acid alone. No reaction was observed under the coupling conditions when the protein did not contain an aryliodide. $^{11}$

A variety of aryl- and vinylboronic acids could also be coupled to the protein (Table 2). It is noteworthy that no organic solvent is used in these reactions. The borate confers water-solubility to an otherwise insoluble substrate and allows efficient conjugation of a 
Table 2. Suzuki-Miyaura Cross-Coupling on a Protein Surface

\begin{tabular}{|c|c|c|c|c|c|}
\hline & & 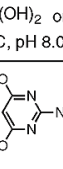 & 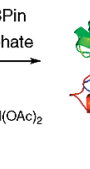 & L-156 Coupl & Product \\
\hline Entry & $\mathrm{R}-\mathrm{B}(\mathrm{OH})_{2} / \mathrm{R}-\mathrm{BPin}$ & Time & $\begin{array}{c}\text { Mass } \\
\text { Calculated }\end{array}$ & $\begin{array}{c}\text { Mass } \\
\text { Observed }\end{array}$ & Conversion \\
\hline 1 & & $30 \mathrm{~min}$ & 27035 & 27035 & $>95 \%$ \\
\hline 2 & $-\mathrm{B}(\mathrm{OH})_{2}$ & $30 \mathrm{~min}$ & 27049 & 27049 & $>95 \%$ \\
\hline 3 & $-\mathrm{B}(\mathrm{OH})_{2}$ & $30 \mathrm{~min}$ & 27053 & 27053 & $>95 \%$ \\
\hline 4 & $-\mathrm{B}(\mathrm{OH}$ & $30 \mathrm{~min}$ & 27060 & 27060 & $>95 \%$ \\
\hline 5 & $\mathrm{~B}(\mathrm{OH})$ & $30 \mathrm{~min}$ & 27113 & 27113 & $>95 \%$ \\
\hline 6 & -B( & $30 \mathrm{~min}$ & 27025 & 27025 & $>95 \%$ \\
\hline 7 & $-\mathrm{B}(\mathrm{OH})_{2}$ & $30 \mathrm{~min}$ & 27051 & 27052 & $>95 \%$ \\
\hline 8 & & $30 \mathrm{~min}$ & 27041 & 27041 & $>95 \%$ \\
\hline 9 & & $60 \mathrm{~min}$ & 27177 & 27176 & $>95 \%$ \\
\hline
\end{tabular}

variety of hydrophobic aryl groups and lipids (entries 1-8). Finally, cross-coupling was used as a route to a synthetic glycoprotein ${ }^{16}$ (Entry 9).

While our main goal was to validate Suzuki-Miyaura crosscoupling in protein modification, we are not insensitive to general synthesis. Indeed, the catalyst mediates efficient coupling of a variety of aryliodides and arylbromides. Selected examples are shown in Table 3. Microwave irradiation was used for rapid coupling, though conventional heating suffices in most cases. The catalyst is functionally tolerant, and phenols, anilines, thiophenes, and pyridines were synthesized in excellent yield. Hindered, ortho-substituted biaryls were also readily accessible (Table 3). These congested couplings are a common testing ground for catalyst activity. ${ }^{17}$ Cross-coupling with this catalyst is also scalable. A 50-g coupling of 4-bromobenzoic acid and phenylboronic acid was carried out in a beaker of water, open to air, using only $0.01 \mathrm{~mol} \% \mathrm{Pd}$. The product crystallizes directly from the mixture and is isolated in excellent yield (97\%). ${ }^{11}$ No organic solvent is needed in the reaction or workup, an important feature in the context of green chemistry. ${ }^{18}$

In conclusion, we have disclosed a convenient, easily prepared $^{11}$ catalyst for aqueous Suzuki-Miyaura cross-coupling. The ligand is commercially available and far cheaper than watersoluble phosphines typically used in aqueous cross-coupling. The catalyst is mild enough to promote cross-coupling on proteins and sufficiently active to mediate hindered biaryl coupling. The cross-couplings reported on protein substrates are the first to proceed to completion and vindicate extensive effort to genetically incorporate cross-coupling partners into proteins. Currently, we are investigating the use of this catalyst in other Pd-mediated transformations in water. We are also exploring the scope of Suzuki-Miyaura cross-coupling in bioconjugation and applications in fluorogenic protein labeling. Progress to this end will be reported in due course.
Table 3. Pd-Pyrimidine Catalyst in Aqueous Biaryl Synthesis ${ }^{a}$

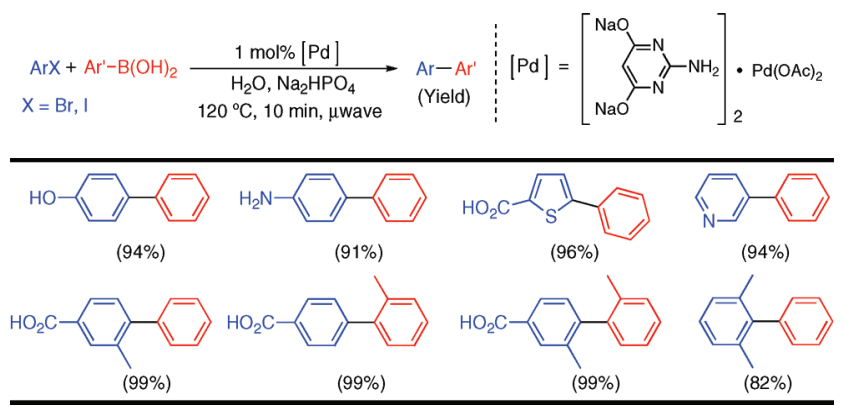

${ }^{a}$ For more examples, TON/TOF analysis, and related control experiments, see Supporting Information.

Acknowledgment. We thank the Rhodes Trust for funding and the National Science Foundation for a Graduate Research Fellowship (J.M.C.). Mitul Patel is acknowledged for technical assistance.

Supporting Information Available: Full experimental details and compound characterization. This material is available free of charge via the Internet at http://pubs.acs.org.

\section{References}

(1) Nicolaou, K. C.; Bulger, P. G.; Sarlah, D. Angew. Chem. Int. Ed. 2005, $44,4442-4489$.

(2) (a) Genêt, J. P.; Savignac, M. J. Organomet. Chem. 1999, 576, 305-317. (b) Shaughnessy, K. H. Eur. J. Org. Chem. 2006, 1827-1835.

(3) (a) Dibowski, H.; Schmidtchen, F. P. Angew. Chem. Int. Ed. 1998, 37, 476-478. (b) Bong, D. T.; Ghadiri, M. R. Org. Lett. 2001, 3, 2509-2511. (c) Ojida, A.; Tsutsumi, H.; Kasagi, N.; Hamachi, I. Tetrahedron Lett. 2005, 46, 3301-3305. (d) Vilaró, M.; Arsequell, G.; Valencia, G.; Ballesteros, A.; Barluenga, J. Org. Lett. 2008, 10, 3243-3245.

(4) (a) Carrico, I. S. Ph.D. Thesis, etd-09082003-09110526, California Institute of Technology (USA), 2004. (b) Kodama, K.; Fukuzawa, S.; Nakayama, H.; Kigawa, T.; Sakamoto, K.; Yabuki, T.; Matsuda, N.; Shirouzu, M.; Takio, K.; Tachibana, K.; Yokoyama, S. ChemBioChem 2006, 7, 134139. (c) Kodama, K.; Fukuzawa, S.; Nakayama, H.; Sakamoto, K.; Kigawa, T.; Yabuki, T.; Matsuda, N.; Shirouzu, M.; Takio, K.; Yokoyama, S.; Tachibana, K. ChemBioChem 2007, 8, 232-238. (d) Brustad, E.; Bushey, M. L.; Lee, J. W.; Groff, D.; Liu, W.; Schultz, P. G. Angew. Chem. Int. Ed. 2008, 47, 8220-8223.

(5) Hackenberger, C. P. R.; Schwarzer, D. Angew. Chem. Int. Ed. 2008, 47, 10030-10074.

(6) (a) Carrico, I. S. Chem. Soc. Rev. 2008, 37, 1423-1431. (b) Gamblin, D. P.; van Kasteren, S. I.; Chalker, J. M.; Davis, B. G. FEBS J. 2008, 275, 19491959. (c) Doores, K. J.; Gamblin, D. P.; Davis, B. G. Chem.-Eur. J. 2006, $12,656-665$.

(7) See Supporting Information for a list of these amino acids.

(8) (a) Davis, B. G. Pure Appl. Chem. 2009, 81, 285-298. (b) Chalker, J. M.; Bernardes, G. J. L.; Lin, Y. A.; Davis, B. G. Chem. Asian J. 2009, 4, 630640. (c) Lin, Y. A.; Chalker, J. M.; Davis, B. G. ChemBioChem 2009, 10, 959-969.

(9) Miyaura, N.; Suzuki, A. Chem. Rev. 1995, 95, 2457-2483.

(10) Phosphine oxidation is a noted problem in bioconjugation. Laughlin, S. T.; Bertozzi, C. R. Nat. Protoc. 2007, 2, 2930-2944.

(11) See Supporting Information for full details.

(12) (a) Sonogashira, K.; Tohda, Y.; Hagihara, N. Tetrahedron Lett. 1975, 16 , 4467-4470. (b) Li, J.-H.; Zhang, X.-D.; Xie, Y.-X. Eur. J. Org. Chem. 2005, 4256-4259.

(13) Formate was included to facilitate reduction of $\operatorname{Pd}(\mathrm{II})$ to $\operatorname{Pd}(0)$, but the arylboronic acid is also capable of this reduction to the active catalyst.

(14) Stabile, M. R.; Lai, W. G.; DeSantis, G.; Gold, M.; Jones, J. B.; Mitchinson, C.; Bott, R. R.; Graycar, T. P.; Liu, C.-C. Bioorg. Med. Chem. Lett. 1996, 6, 2501-2506.

(15) Hermanson, G. T. Bioconjugate Techniques, 2nd ed.; Academic Press: San Diego, 2008.

(16) (a) Davis, B. G. Chem. Rev. 2002, 102, 579-601. (b) Gamblin, D. P.; Scanlan, E. M.; Davis, B. G. Chem. Rev. 2008, 109, 131-163.

(17) (a) Moore, L. R.; Shaughnessy, K. H. Org. Lett. 2004, 6, 225-228. (b) Anderson, K. W.; Buchwald, S. L. Angew. Chem. Int. Ed. 2005, 44, 61736177. (c) Lipshutz, B. H.; Petersen, T. B.; Abela, A. R. Org. Lett. 2008, 10, 1333-1336.

(18) Sheldon, R. A. Green Chem. 2007, 9, 1273-1283.

\section{JA907150M}

